\title{
Material stock and flow analysis within the agricultural building sector based on local database
}

\author{
G. HANCZ ${ }^{1}$, J. KovÁCS ${ }^{2}$ \\ ${ }^{1}$ University of Debrecen, Faculty of Engineering, Department of Civil Engineering, hgabi@eng.unideb.hu \\ 2University of Debrecen, Faculty of Engineering, Department of Civil Engineering, j.kovacss@eng.unideb.hu
}

Abstract. The purpose of the paper is to analyze on micro level the stream of building materials needed for raising cattle. The scope of the produced material flow chart will cover the inflow and storage of the materials. The overall objective of material flow analysis is to contribute to the data inventory development process which is needed to use these construction materials as secondary raw materials in the future. The assessment is based on a concrete new development in a Hungarian region being carried out nowadays as a development and modernization of an existing cattle raising farm. Driven by the concern of resource depletion, further research on higher level, based on larger database will be needed to verify the estimated national level results for the magnitude of growth of anthropogenic stocks.

Keywords: case study, growth of anthropogenic stocks, secondary raw materials, inflow and storage of construction materials

\section{Introduction}

\section{1. scope}

Human-made material stocks accumulating in buildings and infrastructure play a crucial role in the use of material resources. Building including maintaining and operating in-use stocks of materials require again raw materials. Material stocks also create path dependencies due to their longevity [11]. About half of all materials extracted globally by humans each year are used to build up or renew in-use stocks of materials [11]. These stocks are the material basis of wealth $[6,14]$ and provide services such shelter and constitute the physical infrastructure for production and consumption $[6,25]$. Over the period of 1900 to 2010 global material stocks increased 23-fold, reaching $792 * 109$ tons $( \pm 5 \%)$ in 2010 [11]. In the developed countries the building stock and infrastructure constitute more than fifty percent of each country's real capital [1]. A tangible transition toward environmentally sustainable patterns of resource use requires not only a more complete understanding of stock-flow relations but data on in-use stocks. Circularity of resource flows in economic activities, contributing to improved resource efficiency and underpinning human well-being at much lower resource requirements, is at the core of sustainable resource- use strategies and policies instituted in Japan, China, and the European Union $[21 ., 22,28]$. A convergence of material stocks at the level of industrial countries would lead to a fourfold increase of material demand. [9]. According to [1]. sustainability in the construction 
sector sets the goal of preservation natural resources by the means of integrating quantity-related sustainability aspects into design process [11] like absolute reduction in the use of nonrenewable resources, application of standardized dimensions including modular approaches, improving recycling rates to close material loops by reversible building process allowing for disassembling [1], more intensive utilization of existing stocks, improving efficiency of material use - the selection of materials should be based on their environmental performance and their individual service life. However, recycling is not inevitably sustainable, that is, the absolute reduction of use of materials cannot be achieved solely by recycling since these processes may be very energy demanding and the final purpose of the recycled materials will determine the quality and consequently the appropriate process. The objectives of saving energy and reduction of material use are conflicting in certain cases such as energy demanding recycling techniques and using insulation products to reduce the energy consumption of the buildings. Maybe the hierarchy of these two aspects need to be decided upon with respect to climatic conditions. Furthermore, material stocks expressed merely in tons does not evidently reflect unsustainable use of materials since it involves renewable construction materials as well. For this reason, the environmentally weighted material consumption (EMC) as an indicator for the environmental impact of resource use was developed. The idea behind the EMC is simple: multiply the material flows with a factor representing their environmental impacts [20].

As for the importance of agriculture in a country's economy it plays a strategic role in the economic development of a country. It has contributed significantly to the economic growth of advanced countries and it is of vital importance in the economic development of less developed countries [16].

A few notions and facts representing economic approaches starting with the document of sustainable development at the first place are the following:

- In the 20th century a boost in size and a transformation of the composition of the manufactured capital, as well as the globalization of material supply chains. Both developments contributed significantly to human well-being but also changed the spatial and temporal patterns as well as the scale of the associated environmental pressures [14].

- Manufactured capital is expressed in the form of products capable of providing services that are desired: mobility, communication, cooking, shelter, and so forth. Unlike financial capital or materials use, however, information on product stocks over time is widely scattered and has been regarded as of uncertain integrity.

- According to the OECD [23], G8 countries halved their resource intensity between 1980 and 2008, and Canada, Germany, Italy, and Japan have succeeded in decoupling direct material consumption from economic growth in absolute terms. Direct material consumption is defined as the total amount of material directly used in an economy, i.e. it equals domestic extraction plus imports minus exports. Wiedmann et al. [33] propose that material-efficiency policies should be informed by indicators, such as the material footprint, that consider the increasing spatial separation of production and consumption.

- Decoupling the use of natural resources and associated environmental impacts from economic growth is the main goal of achieving sustainable development and "green economies" [29]. 
Studying published papers in this field we find that the building sector is a separate sector characterized with the activity of construction. But this sector does not construct buildings for its own usage but for other sectors: dwelling, industry, agriculture, institutions, etc. The building material stock will accumulate in the sectors served by these buildings. That is why the question arises: "What kind of material fluxes are generated by agriculture? What kind of material stocks can be related with agriculture?"

As for the building materials, agricultural production demands the services provided by buildings and roads. The general role of farm buildings is to protect the farmer and livestock from predators, to help to control livestock diseases and parasites, to provide shelter against extreme weather conditions, to provide storage of farm produce and other variable inputs and to increase efficiency of production and management in the farms. Roads of agriculture ensure access to other related facilities, access for transport, availability of services, access to dwellings and access to watercourses or footpaths [7].

\section{Literature}

\subsection{History, recent advances and publications in the field of material stock and flow analysis}

Material flow analysis (MFA) is an established approach which allows understanding material flows. MFA is defined as -systematic accounting of the flows and stocks of materials within a system defined in space and time. It connects the sources, the pathways, and the intermediate and final sinks of a material. Because of the law of conservation of matter, the results of an MFA can be controlled by a simple material balance comparing all inputs, stocks, and outputs of a process [4]. Understanding material flows can help us concentrate the resource policy measures on those materials and sectors of the economy with the narrowest supply bottle necks, with the highest optimization potentials and the lowest environmental impacts in the short term and in the long term. MFA can

- provide early warnings of problems lying ahead

- identify potentials for improvements

- show if the economy is on the right path with respect to resource productivity

- provide a basis for determining the environmental impact of resource use [20].

MFA can play an important role in connection with sustainable development in such a way that sustainable material management is part of the product quality management. This results in reduced consumption and environmental impact while maintaining or improving product quality. The material intensity of a national economy (total material requirement /Physical Trade Balance) is one of the fifty-five indicators for sustainable development defined in the Sustainable Development Strategy [20].

During the historical development of MFA, it was underestimated as a basic tool in economics, environmental management, resource management, and waste management. Further application areas of MFA according to [4.] are industrial ecology and anthropogenic metabolism which investigates among other issues the unprecedented growth, the order of magnitude of anthropogenic 
flows overgrowing natural ones and the growing rate of material stocks. One main reason for applying MFA for measuring material stocks is that it holds a tremendous potential for future recycling.

With respect to the objective of this study the potential uses and the limits of MFA in the field of the growing rate of material stocks and the differences between MFA and other similar approaches such as pathway analysis, input-output analysis, and LCA are the main methodological questions.

The application of MFA for resource management is of prime importance for analysis and planning of resources. It is the basis for modelling resource consumption as well as changes in stocks, and therefore it is important in forecasting the scarcity of resources. MFA can help in identifying the accumulation and depletion of materials in natural and anthropogenic environments. Balancing all inflows and outflows of a given stock provides information on the time period until the stock reaches a critical state of depletion or accumulation [4].

These materials may become secondary resources and contribute to closing material loops, or they have to be disposed of [11]. Resource management is carried out not only on regional and national but on continental and global level. Therefor it is indispensable to carry out the analysis in a comparable way, for example using the same categories of materials in every country. Categories of materials extracted from the territory of the country inputs according to the Interest Group on the Sustainable Use of Natural Resources on the needs for further development of MFA-based indicators are [20] raw materials ( biomass from agriculture, forestry and fishing, fossil fuels and minerals) and finished products. In order to reduce the number of parameters as much as possible, indicator elements representing all the materials which are the subject of the analysis are to be selected [4].

\subsection{The importance of case studies in this field}

According to [1] on sustainable construction barriers to progress among others are linked to lack of data and lack of communication among existing datasets. Building stock studies focus mainly on urban buildings (that is, residential, commercial, industrial, and public buildings).

The building stock represents a large amount of societal wealth, constitutes one of the largest anthropogenic repositories of raw materials and generates high levels of construction and demolition waste. Current discussions on the building stock generally focus on energy consumption. The concept of Urban Mining can help to shift this focus by viewing buildings as raw material repositories whose intelligent management has tremendous potential for conserving our reserves of raw materials. Urban Mining aims to bring the materials released by buildings back into circulation. This requires information on the stock and its dynamics [32]. Basically, the same databases are used for lifecycle assessments. Recent developments in LCA discusses several aspects of data development - not only lack of data but the usefulness of aggregated industry data, reliableness and representativeness, missing transparency and possibilities of hidden biases and, suggesting the importance of ensuring the quality of such databases [22]. The UNEP/SETAC Life Cycle Initiative and the International Reference Life Cycle Data System are trying to address inventory data, among other things, in the contexts of consistency and quality assurance building on existing examples and achievements, e.g., the ISO TC 14048. Another and complementary approach to help support the exchange of data amongst the many 
LCA tools and databases in current practice is a format conversion tool, to convert LCA data formats from one to another [22].

There are far less studies on rural buildings and most studies explicitly exclude sheds, storage, and barn constructions. Therefore, data on the material stock of buildings related to agriculture could contribute to the field of research of recycling demolition wastes in the future and to improving resource efficiency in the present.

A prerequisite of the efficient recycling of demolition waste is information on the composition of the building material stock as the source of future demolition waste.

Case studies like this provide data on the construction material inflow which becomes building material stock with the completion of the construction process, until demolition. The case study is based on the analysis of the construction documents.

A German study [26] calculated the total material mass of non-residential buildings is approximately 6.8 billion tons, accounting for $44 \%$ of the entire building stock in Germany. These results indicate the significance of the embedded natural resources. Thus, a greater focus on the non-residential building stock would improve the efficient use of resources.

\subsection{Similar published case studies and their findings - a starting point}

A study from 2014. states that better construction and use of buildings in the European Union would influence more than $50 \%$ of all extracted materials [2]. The research uses an extensive literature study and a case-study to assess: should the depletion of materials be ignored in the environmental or sustainability assessment of buildings and what is the significance of scarce materials, compared to the use of other building materials [2].

As for the scarcity of mineral building materials the building industry uses large amounts of materials, equating to approximately $50 \%$ of European resource extraction, but the most common building materials are also common in nature [2]. Aggregates, for example, are the key component of many building elements but are generally not a scarce resource [2]. However, due to their heavy and bulky nature, aggregates need to be sourced close to their markets [2]. Viable sources may be constrained at regional and local level if their viable local supply is not strategically planned [2]. Relating to these problems, approaches which account for local resources have been proposed in literature [13].

A study carried out in Finland [2] was founded on the premise that the importance of material efficiency is based on - among other impacts - the depletion of raw materials and its long-term socioeconomic impacts viewed from the perspective of sustainable development. Material efficiency is emphasized as an important aspect of sustainable building, as indicated by the inclusion of the abiotic resource depletion potential as an aspect in related regulations [9] and the inclusion of the new basic requirement for sustainable use of resources in the Construction Product Regulation [10]. Only 0.7\% of the abiotic material mass inputs of the case building - a typical Finnish six-storey residential building with a basement floor - had a characterization factor making the abiotic resource depletion potential elements assessment practically worthless. The basic issue behind this was that such factors cannot be defined for any of the common building materials, such as gypsum, silica, sand, construction 
sand, clays, limestone, and such, due to lack of data on material configurations, reserves, reserve bases and ultimate reserves for these materials [2]. The result of the study raised the questions of whether the ADP elements assessment method is appropriate for the assessment of buildings and construction.

Another study [24] presents results from exploring the adaptation of existing built environments with the objectives for sustainable future. The subject of this study was the retrofitting activity in the commercial property sector in Bristol, the UK, but it also addressed non-domestic buildings as well. The starting point was the relative environmental advantage of retrofitting existing buildings compared to demolishment and new construction as several studies point out [24]. According to the study a major work has been done to develop a UK national database on non-domestic buildings with the result that compared with the domestic stock, the non-domestic building stock is very diverse, complex and heterogeneous. To illustrate this, if the housing stock can be effectively represented by 1000 dwelling types, the non-domestic stock would need maybe 100000 building types. Many nondomestic buildings have mixed use and mixed construction, coming in a huge range of shapes, size and materials. It also states that the boundary between domestic and non-domestic purpose of use is not always clear [24].

A thesis from 2012. [12] charts the dynamics of change in periurban agricultural building stock in Sweden and the underlying reasons for these changes with the purpose of evaluating the possibilities of reusing them in truism sector. Additional field studies examine the connections between human behavior patterns/lifestyle and the use of built periurban infrastructure, including analyses of functions, use of materials and issues concerning aesthetics. Finally, actual tourism enterprises using agricultural building $\mathrm{s}$ in Sweden are examined in terms of sustainability issues. A study from the Netherlands [30] shows that $85 \%$ of the new functions developed in former agricultural buildings have to do with dwellings, while $15 \%$ are connected to non-agrarian activities, although even in the latter case, most of these activities are combined work-home residences. It raises the question of appropriateness of the method to categorize buildings based on their functions. The more so because one way of intensifying in use material stocks is to find a function to them instead of demolishing.

Preservation and reuse of agricultural buildings is an important issue in other countries, among others Norway, Ireland and the UK [12]. International literature categorizes agricultural buildings for various purposes and based on different approaches and factors, such as building material, construction technology, influence on the landscape, use and function, size, age, character (modern/traditional, etc.), aesthetic qualities, heritage values and monetary value, etc. [12].

This hierarchy of aspects is important from our point of view because the recent category of buildings does not take sustainability aspects into consideration and the aspect of "material” has lost its weight ( figure 1.). Maybe a third group for the latest generation of agricultural buildings should be developed with the current aspects related to sustainability and the weights thereof. Hopefully the weight of these aspects could be bigger even at the others' expense. 


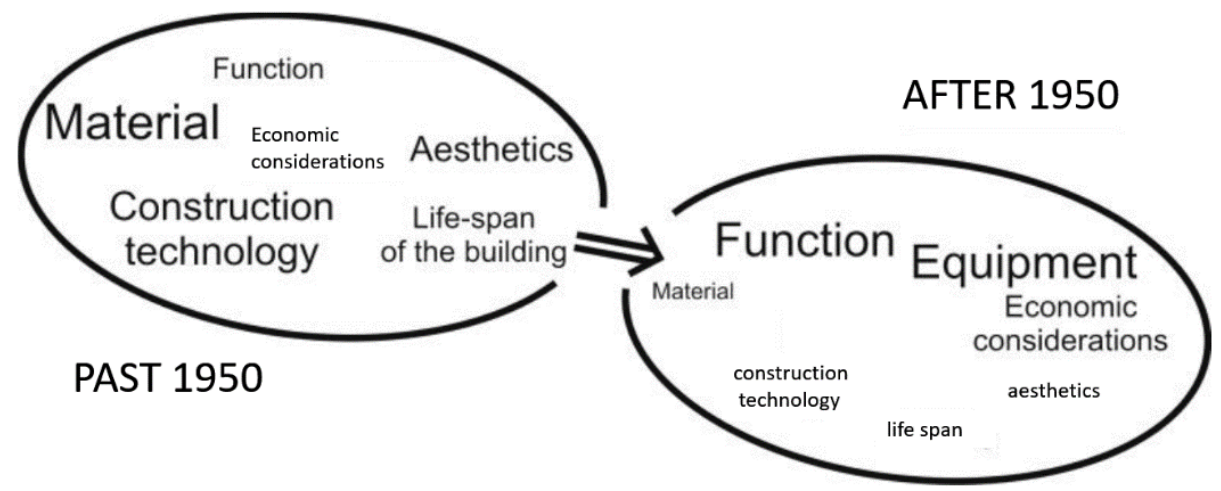

Figure 1. Changes in importance of factors concerning the erection of agricultural buildings from the farmers' point of view; adapted from [12].

\subsection{Examples of case studies of buildings and roads in other sectors}

The German study mentioned earlier [26] introduces the review of earlier studies categorizing nonresidential buildings with the purpose of developing a database. The literature provides several different examples of this, which differ according to the objectives pursued but material-specific typologies in the strict sense are currently unavailable. While national statistical agencies provide information on the residential building stock, there is a general lack of data on the stock of nonresidential buildings [26]. Bottom-up approaches supply much more detailed information on the constitution of the building stock. The basic principle of the Bottom-up approach is to define indicators that describe characteristic material compositions of typical buildings (material composition indicators - the authors define material composition indicator as a specific weight of the materials in $\mathrm{kg} / \mathrm{m}^{2}$ ) as well as indicators to estimate the physical size of the building stock in terms of some particular measure (e.g. floor space) [26].

Only a small number of studies have attempted to fill this gap by providing estimates of building stocks, for example in Austria, Switzerland, Germany, France, United Kingdom, Italy, Spain and New Zealand. In most cases, these studies have focused on a concrete building sector such as heated nonresidential buildings or social infrastructure rather than the entire stock. Differentiated material composition indicators for various nonresidential building types are available e.g. for Germany, Austria, France and Japan [26].

Some specific data on agricultural buildings are reported in the study, these are:

- material stock in existing German agricultural buildings is 473 million tons

- as for the relevance to urban mining, buildings also contain economically interesting raw

materials such as metals. In the case of Germany's stock of buildings, these materials are present in considerably higher proportions in nonresidential buildings than in residential buildings

- Germany's official statistics on buildings classifies the non-residential stock into seven main types, one of which is agricultural commercial buildings. The MCI for this usage type of buildings is $1.1 \mathrm{t} / \mathrm{m}^{2}$ of floor surface which is lower than that of any other type 
- the material composition indicator for Japanese agricultural buildings ranges from $1.0 \mathrm{t} / \mathrm{m}^{2}$ for wooden frame constructions to $3.9 \mathrm{t} / \mathrm{m}^{2}$ for reinforced concrete constructions.

- The adopted method to produce MCI for nonresidential buildings [28] constitutes three steps

1. The sources for this calculation are based on information provided by the planners of about 1000 new objects - built in the period 1976 to 2010 - categorized into 38 groups eight of which were analyzed for the purpose of the study. A date sheet is provided for each object construction plans, containing general information such as the year of construction, location and type of use, as well as data on areas and volumes, building element descriptions and costs. Based on these data and density parameters, the first stage involves the determination of $\mathrm{MCI}_{\mathrm{s}}$ for structural variants of building elements: specific $\mathrm{MCI}_{\mathrm{e}}\left[\mathrm{kg} / \mathrm{m}^{2}\right.$ es] element surface (es) (e.g., exterior wall designed as mullion-transom construction

2. The second stage gives a description of general MCIs for building elements by considering the frequency of occurrence of the structural variants within a building element of a specific building type: general $\mathrm{MCI}_{\mathrm{e}}\left[\mathrm{kg} / \mathrm{m}^{2}\right.$ es]. This step is based on the additional data of frequency of occurrence of elements in per cent in the investigated building type

3. building $\mathrm{MCl}_{\mathrm{b}}\left[\mathrm{kg} / \mathrm{m}^{2}\right.$ fs] for the whole floor surface of the building

The authors conclude that the main difficulties in determining material stocks are:

- difficulty in specifying the material composition of the NRB stock

- gaps in databases undermine the general validity of final stock estimates

In our study we cannot determine the $\mathrm{MCI}_{\mathrm{b}}$ for the buildings because we do not have quantitative data for the reused building elements.

\section{Material and methods}

\subsection{The aims of this study}

In our study we aim to

- determine the rate of change of the agricultural building stock resulting from the building and road construction carried out on the level of the introduced agricultural development project

- estimate the rate of change of the agricultural building stock resulting from the building and road construction activity supposedly carried out in the frame of the introduced rural agricultural development program

As it is underlined in the literature gaps in data regarding nonresidential building material stocks are large and wide-ranging studies can make use of the results deriving from smaller case studies. Accordingly, this study may advance our knowledge in the field of building material stocks in the agricultural sector. The general approach of MFA and material stock analysis is used in the study. We aim to determine the above-mentioned values using the well-established method of MFA and the 
method adopted in the German study [26]. To carry out these calculations we use direct data source from the planner of an agricultural farm reconstruction plan including several buildings and service roads within the farm property.

This section presents the case-study construction project and explains the MFA method and describe the main data sources used in the study.

\subsection{Detailed introduction of the method of MFA}

To introduce the method of MFA, we refer to Brunner et.al [4] who establish the method step by step. Based on the relevance to the case study we introduce in detail a selection of terms, definitions, procedures carried out during MFA.

\subsubsection{What is the difference between the terms, substance, material and goods?}

A substance is any element or compound composed of uniform units. All substances are characterized by a unique and identical constitution and are thus homogeneous. In MFA, chemical elements and compounds both are correctly addressed as substances. In MFA goods are defined as economic entities of matter with a positive or negative economic value. Goods are made up of one or several substances. In MFA material serves as an umbrella term for both substances and goods.

In the case study we use the term material however the dataset is based mainly on goods or products built up of more than one substance.

\subsubsection{What processes are going to be analysed?}

Process is defined as the transformation, transport, or storage of materials.

In the case study we analyse the process of storage. Materials are converted into buildings and roads. Materials -construction materials -are transported to the construction site but the goal of the study is to analyse the change in the rate of stock. The total amount of materials stored in a process is designated as the "stock of materials" in the process. Both the mass of the stock as well as the rate of change of the stock per unit time (accumulation or depletion of materials) are important parameters for describing a process. A "final sink" is a process where materials have very long residence times $\left(t_{R}\right.$ $>1000$ year).

In the case study we use the term storage of materials. They are not supposed to have longer residence time than decades so there is no final sink within the boundary.

\subsubsection{How is temporal and spatial system boundary defined?}

The system is the actual object of an MFA investigation. An open system interacts with its surroundings; it has either material or energy imports and exports or both. A closed system is conceived as a system with complete

isolation, preventing material and energy flows across the system boundary. A single process or a combination of several processes can represent a system. 
The temporal boundary depends on the kind of system inspected and the given problem. It is the time span over which the system is investigated and balanced.

In the case study we define the temporal boundary of the investigated anthropogenic system as one year for which period data are available.

The spatial system boundary is usually fixed by the geographical area in which the processes are located.

This is the case with our case study as well. The spatial boundary of the system is the boundary of the agricultural property where the development is carried out. The address is 4200 Hajdúszoboszló, periphery, parcel identity number $057 / 3$. The area is 8.1 acres (Figure 2.) We use the same boundary line as it is offered in the original method [4]

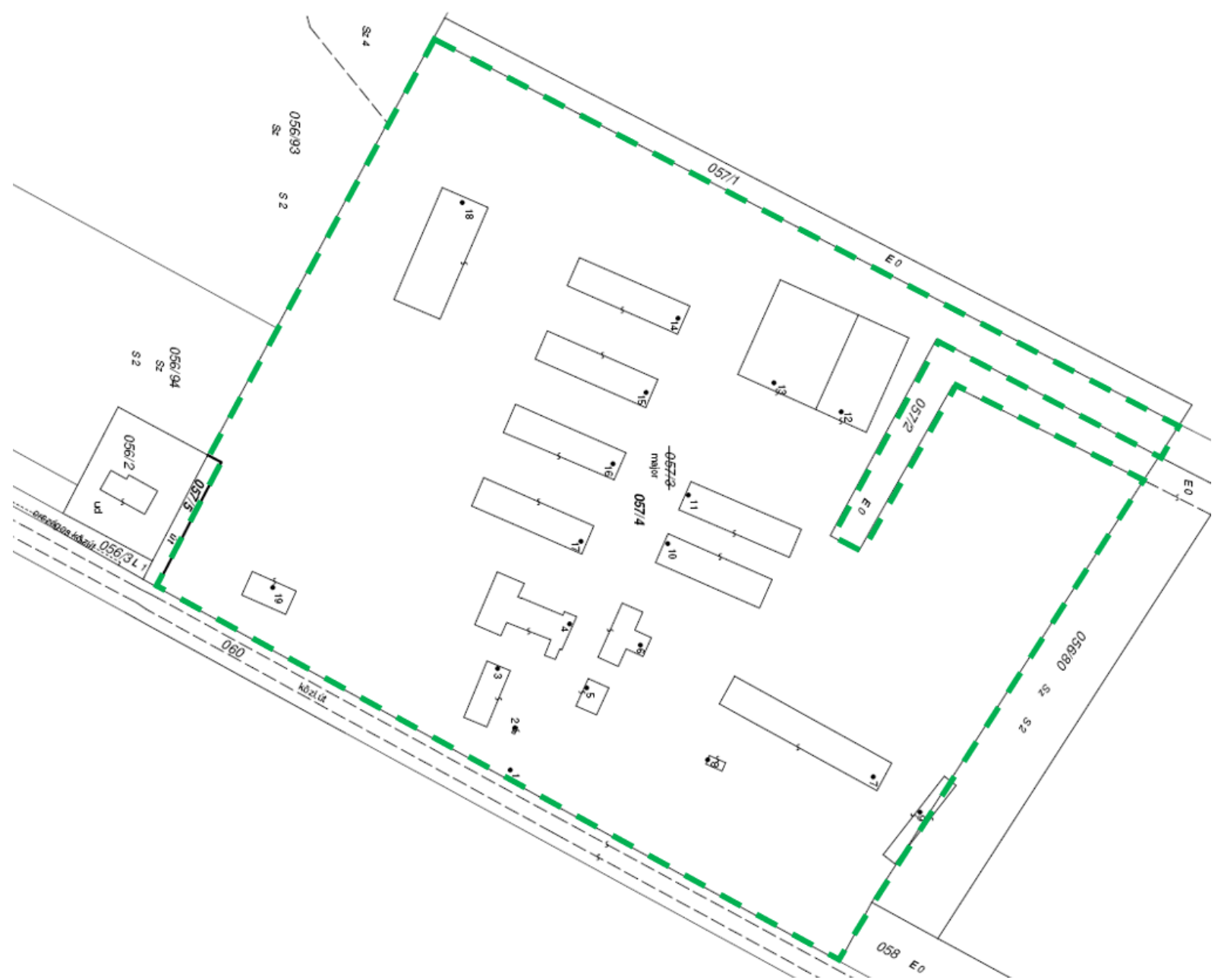

Figure 2. The spatial boundary of the system of the case study determined by the boundary of the agricultural property based on official surveyor's map produced after the project was carried out in 2017. (The Identity Number has changed in the meantime due to dividing the area in two.) 


\subsection{Detailed introduction of the case study}

\subsubsection{Location}

The farm is in Hungary, Hajdú-Bihar County, in the Southeastern periphery of the town Hajdúszoboszló, about 11 km-s far from Debrecen on road (Figure 3.):

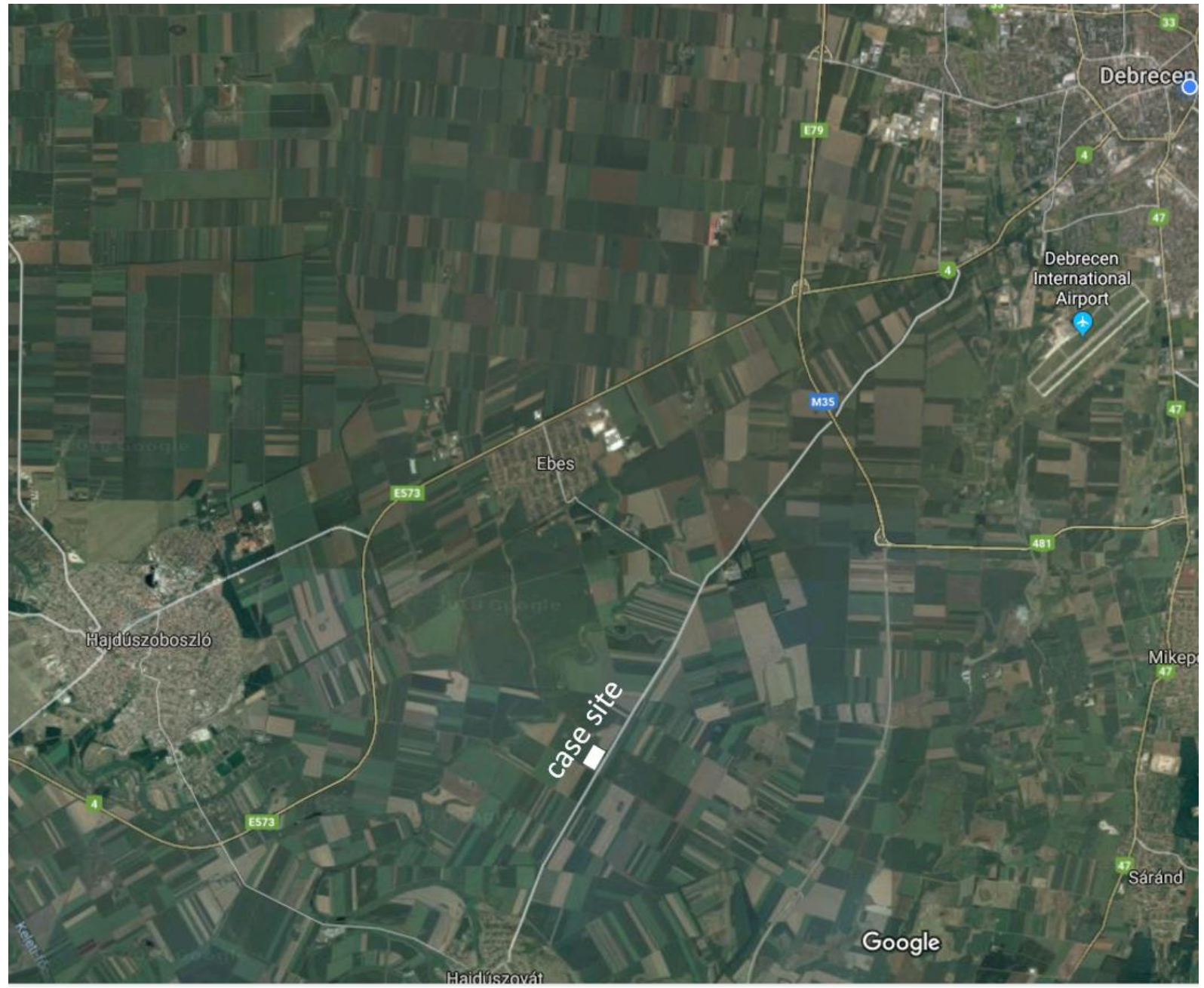

Figure 3. Location of the case site [Source: google maps]

\subsubsection{Existing buildings and infrastructure}

In Table 1. and 5. we introduce the existing buildings, their current and planned function and whether the planned development effects these establishments or not. In the last column we indicate the impact of the current stock of building material within the system boundary.

\subsubsection{Planned replacements}

Seven cattle barns, six of which are uniform, is planned to be replaced with new structures with the reuse of some of the structural elements. 


\subsubsection{Planned demolitions}

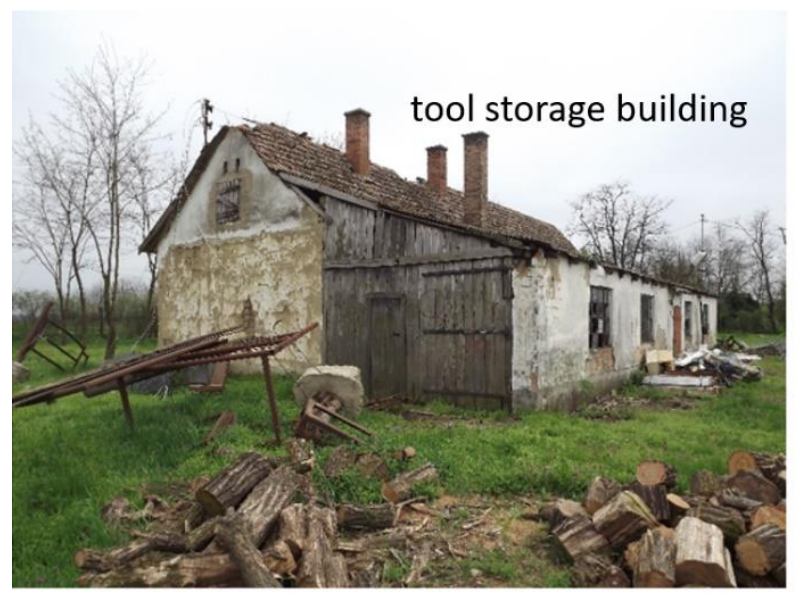

a tool storage building to be demolished, number 07

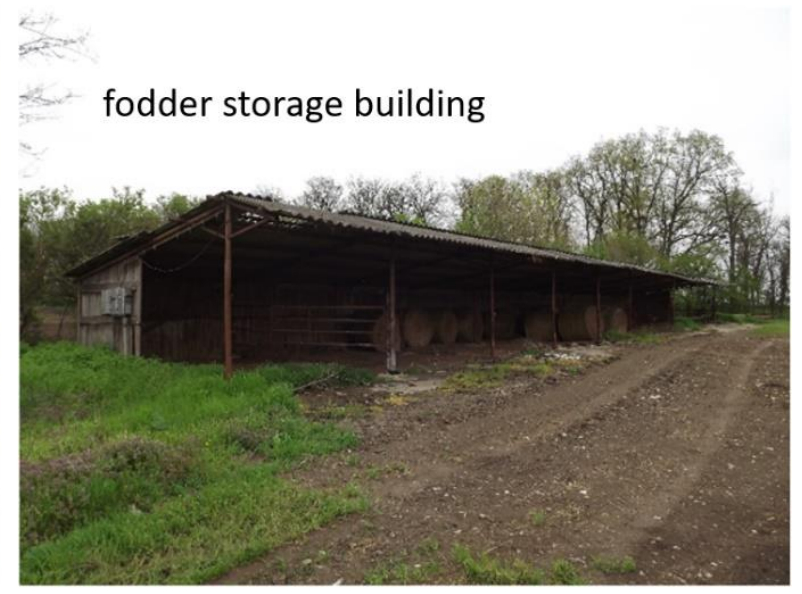

a fodder storage building to be demolished, number 08 Figure 4. Picture of obsolete buildings number 7 and 8

Two existing storage buildings - number 7.,8. in the layout - are to be demolished without replacement ( Figure 4.). A statistical datasheet belongs to the building design documentation. According to that the reason for demolition is obsolescence. The buildings were built between 1920 and 1944. The built-in area of the buildings is $202,5 \mathrm{~m}^{2}$. The building material is brick, adobe, and wood. 
International Journal of Engineering and Management Sciences (IJEMS) Vol. 3. (2018). No. 5

DOI: 10.21791/IJEMS.2018.5.30.

\begin{tabular}{|c|c|c|c|}
\hline $\begin{array}{c}\text { number of } \\
\text { establishments } \\
\text { in the layout }\end{array}$ & $\begin{array}{l}\text { current and/or } \\
\text { planned function }\end{array}$ & the planned change & $\begin{array}{c}\text { impact on stock } \\
\text { decrease or increase }\end{array}$ \\
\hline 1 & porter's lodge & \multirow{10}{*}{$\begin{array}{l}\text { existing buildings } \\
\text { not to be replaced }\end{array}$} & \\
\hline 2 & social building & & \\
\hline 3 & storage building & & \\
\hline 4 & storage building & & \\
\hline 5 & building & & \\
\hline 6 & barn & & \\
\hline 7 & $\begin{array}{l}\text { storage building to be } \\
\text { demolished }\end{array}$ & & D calculated $^{\text {not }}$ \\
\hline 8 & $\begin{array}{l}\text { storage building to be } \\
\text { demolished }\end{array}$ & & D ${ }_{\text {calculated }}^{\text {not }}$ \\
\hline 9 & manure storage facility & & \\
\hline 10 & firewater storage & & \\
\hline 11 & cattle barn & \multirow{7}{*}{$\begin{array}{c}\text { SEVEN } \\
\text { CATTLE BARNS TO } \\
\text { BE REPLACED, SIX } \\
\text { OF WHICH IS } \\
\text { UNIFORM }\end{array}$} & I calculated \\
\hline 12 & cattle barn & & I calculated \\
\hline 13 & cattle barn & & I calculated \\
\hline 14 & cattle barn & & I calculated \\
\hline 15 & cattle barn & & I calculated \\
\hline 16 & cattle barn & & I calculated \\
\hline 17 & cattle barn & & I calculated \\
\hline 18 & fence & \multirow{4}{*}{$\begin{array}{c}\text { new establishments } \\
\text { - expansion and } \\
\text { technical } \\
\text { development }\end{array}$} & I \\
\hline 19 & paving block road & & I calculated \\
\hline 20 & concrete road & & I calculated \\
\hline 21 & truck scale & & I not calculated \\
\hline
\end{tabular}

Table 1. Existing establishments in the system corresponding with the layout 


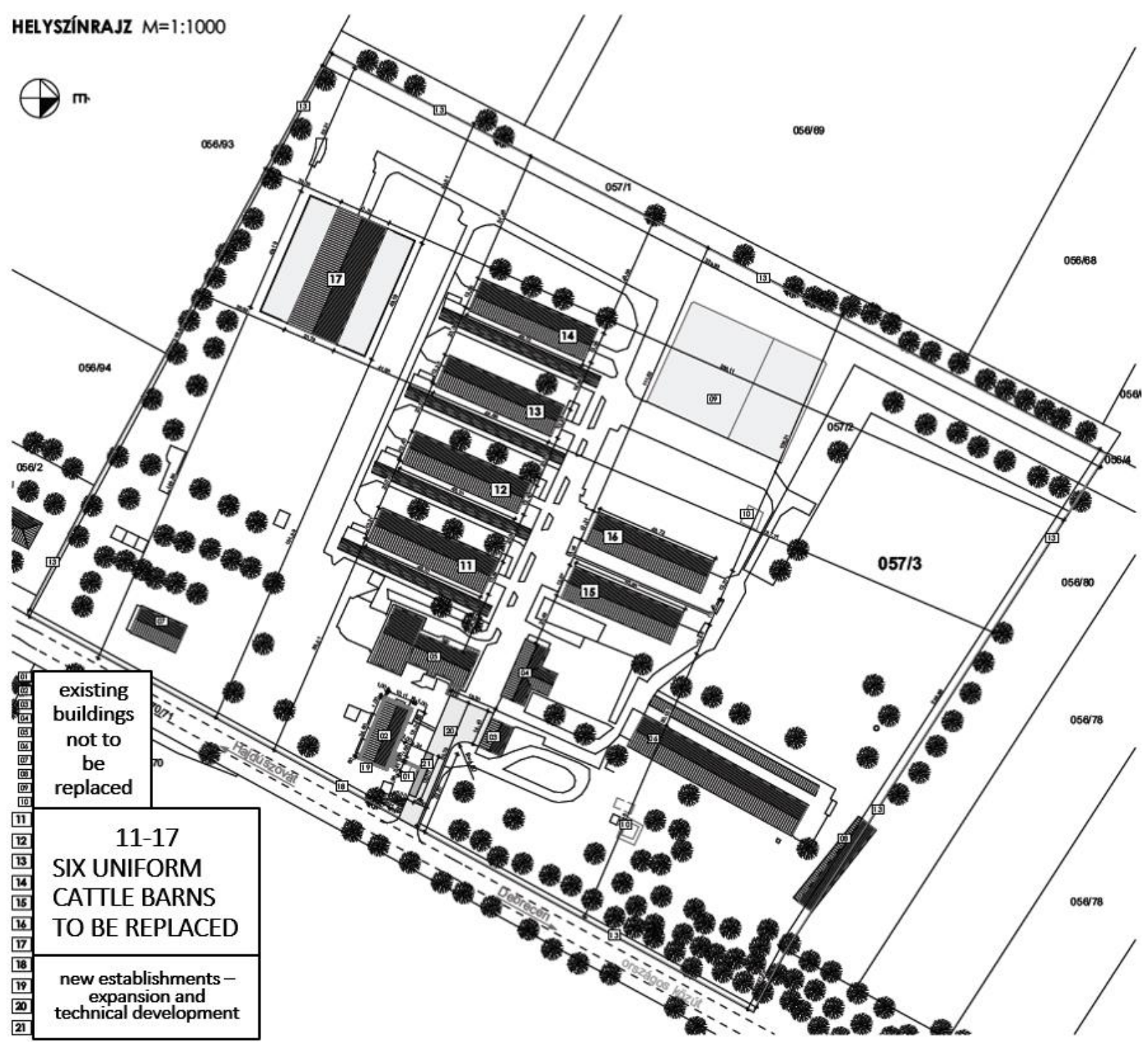

Figure 5. Site layout with the existing buildings and other establishments - ten of them are not subject of replacement; six uniform cattle barns are replaced by new buildings; four of them are new establishments

\subsubsection{Input data}

- The input data is an object database of newly designed NRBs, based on information provided by the planner of these new objects. The material quantities required for the assessments of the product stage were based on the bill of quantities of the real-world case building, which is described in further detail later. Generally, a bill of quantities indicates a document to be implemented for tendering purpose in the construction industry. The task of a bill of quantities is to index all the details for materials, parts, and labor and their costs. The entire bill of quantities contains project related measured quantities of the items of work recognized with the drawings and specifications available in the tender documentation. The bill of quantities is a schedule that sorts, details and computes the materials and other cost items which are implemented in the construction project, offering a high level of accuracy in material amounts. For calculation purposes, the items, units and quantities of materials are listed in the study categorized under two groups, namely: building and road construction. We cannot categorize 
the products according to their raw material content - such as aluminium, concrete, copper, fossil materials, gravel, other mineral resources, steel, wood - so we can only calculate the total mass of built-in material.

- As it is not the aim of the building design documentation nor of the bill of quantities to calculate the mass of flow of materials, the quantities for some products are given in meters or cubic meters or pieces. For these products data of specific mass per cubic meters or per meter or per piece was searched for in product specifications on the dealers' websites.

- As for the national level estimation of building material stock in the agricultural sector the only statistical data from year 2000 is the number of cattle barns in Hungary which was thirty-nine thousand [19]. Having no data on material content of existing barns, a more promising approach of estimating this amount is the sum of the total available funding addressed to the animal husbandry and milk production within the rural development program under code VP2-4.1.1.3-16 [15]. With a total contribution of more than EUR 4.2 billion for measures benefiting its rural areas (EUR 3.4 billion from the EU budget and EUR 740 million of national co-funding), the 2014-2020 Rural Development Programme for Hungary emphasizes the priorities of restoring, preserving and enhancing ecosystems and developing viable farms, increasing economic performance of agricultural holdings promoting food chain organizations and risk management in agriculture. The total sum to be awarded until 2020. is 69 million Euros for the modernization of the cattle breeding sector by building new stables and modernize the elements of the applied technology resulting in increasing milk production and number of animals [5]. As a result, we get the volume of projected input into building stocks in the cattle razing branch of the agricultural sector alone.

\subsection{THE DEVELOPMENT OF AN MFA}

Here we introduce the consecutive steps to be taken when doing an MFA according to Brunner et.al. [4].

\subsubsection{Relevant material}

Identify the key material flows - relevant matter, goods, or indicator substances along with the relevant processes.

\subsubsection{System boundary in space and time}

Determine the system boundary in space and time corresponding with the level of collected information. 


\subsubsection{Identifying and quantifying the mass of flows and stocks of goods / materials}

Quantifying the mass of flows of goods / materials using data of different possible sources. These sources can be literature, measurements, calculations, direct sources of information, estimates based on reasoning, expert judgement and/or probability assessment.

\subsubsection{Interpretation of results}

Practical and informative way of interpreting results is graphical presentation. For this purpose, we adopt the figure published in [4], neglecting those elements - air, off-gas, water, fossil fuels, etc., for which we do not have data (Figure 6.).
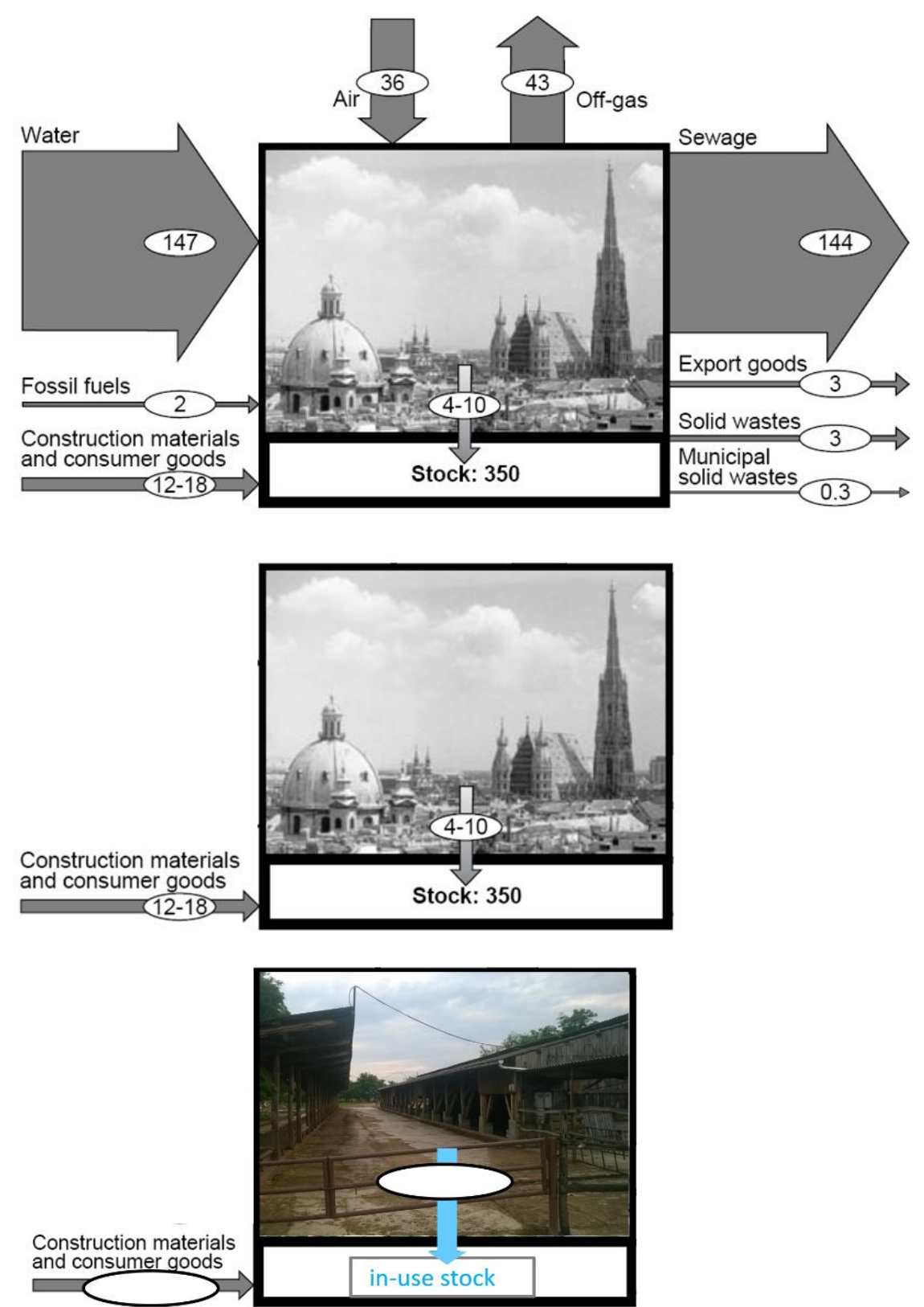

Figure 6. The results of the building material stock analysis can be represented by the figure adopted and simplified from [4] 


\section{Results}

\subsection{RELEVANT MATERIAL}

The category of relevant goods/ materials is construction materials, most of which are not raw materials but products.

The direct source of data used in this case study is the design documentation provided by

the designer himself who prepared the principal building design documentation and provided the documentation in PDF format for us for research purposes:

- building layout plan;

- $\quad$ architectural part;

- $\quad$ structural part

- description of the construction work,

- the construction cost budget,

- utility works, roads, lots, landscaping in relation to the geodetic system and other objects located in the same area.

In table one we indicate which project elements are subject of the study regarding the mass of built-in construction material. Based on the bill of quantities we can produce an accurate calculation of the total mass of material (Table 1.). Fat letter type is used for elements of the projects that increases or decreases the current size of the building stock within the system boundary. These elements along with the products used for their construction and the specific and total weight are calculated in excel in Table 2. Sources of technical facts regarding the products are among the references $[17,18,3]$. 
International Journal of Engineering and Management Sciences (IJEMS) Vol. 3. (2018). No. 5

DOI: $10.21791 /$ IJEMS.2018.5.30.

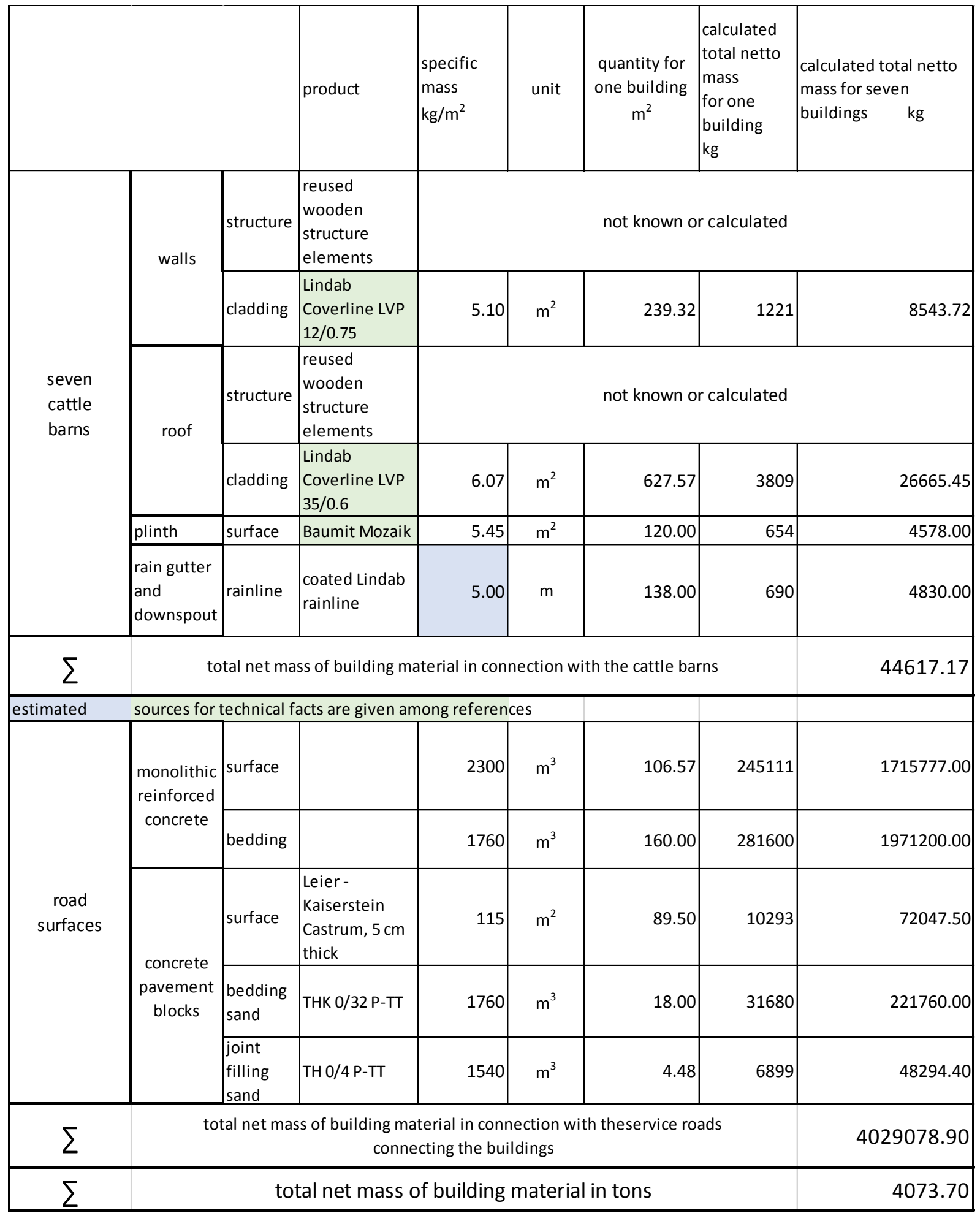

Table 2. Elements along with the products used for their construction and the specific and total weight are calculated in excel 


\subsection{SYSTEM DEFINITION IN SPACE AND TIME}

The spatial system boundary is determined in two steps:

1. The spatial system boundary is determined by the scope of the project which is a farm because information is collected on this level. The timescale is also determined by the scope of the development project.

- spatial system boundary: one local farm

- $\quad$ system boundary in time: one year

2. In the study we make a rough estimation by extending the system boundary in space and time in accordance with the financial resources available until 2020. in the frame of the national rural development tender project under the code VP2-4.1.1.3-16.

- spatial system boundary: Hungary

- $\quad$ system boundary in time: three years

\subsection{QUANTIFYING THE MASS OF FLOWS OF GOODS / MATERIALS}

According to the mass-balance principle, the mass of all inputs into a process equals the mass of all outputs of this process plus a storage term that considers accumulation or depletion of materials in the process [4].

\subsubsection{On the farm level:}

$$
\sum m_{\text {input }}=\sum m_{\text {output }}+m_{\text {storage }}
$$

As the depletion of the materials in the process is not known, the whole input equals the accumulation of materials within the system boundary as stock.

$$
\sum m_{\text {input }}=4073.7 \text { tons }=m_{\text {storage }}
$$

Figures 7. and 8. represent the results of the analysis. The difference between the information held by the figures is that Figure 7. indicates that other activities are also present within the system boundary. Both types of figures are appropriate for representing the results. 


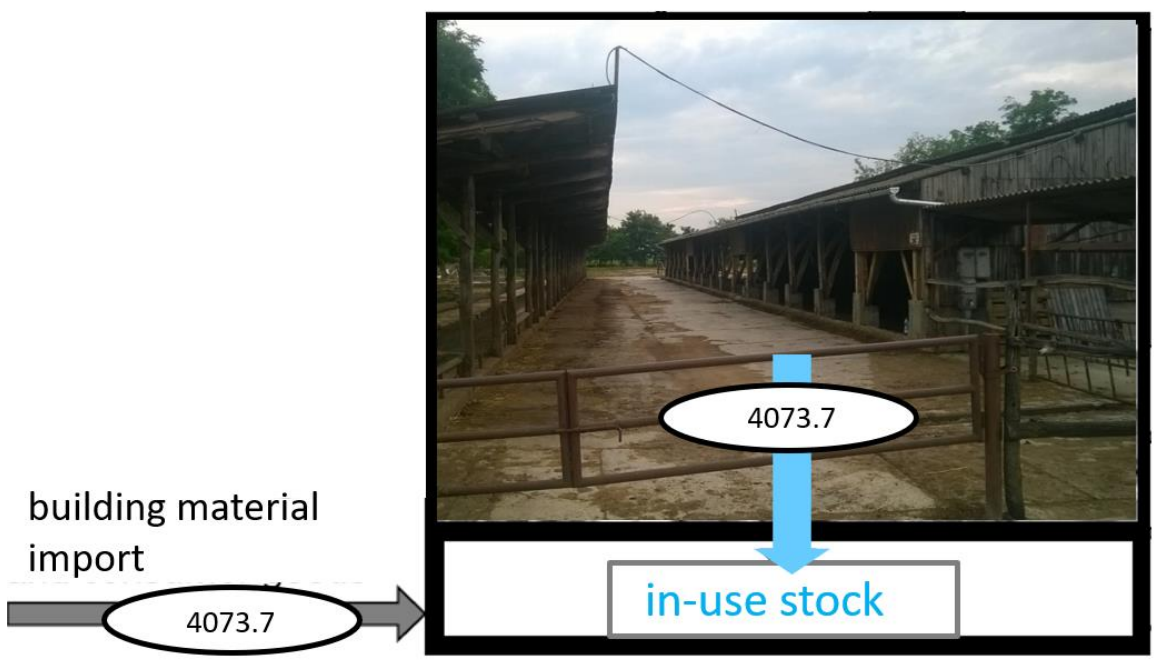

Figure 11. Farm-level growth of in-use building stock in tons as a result of a development project

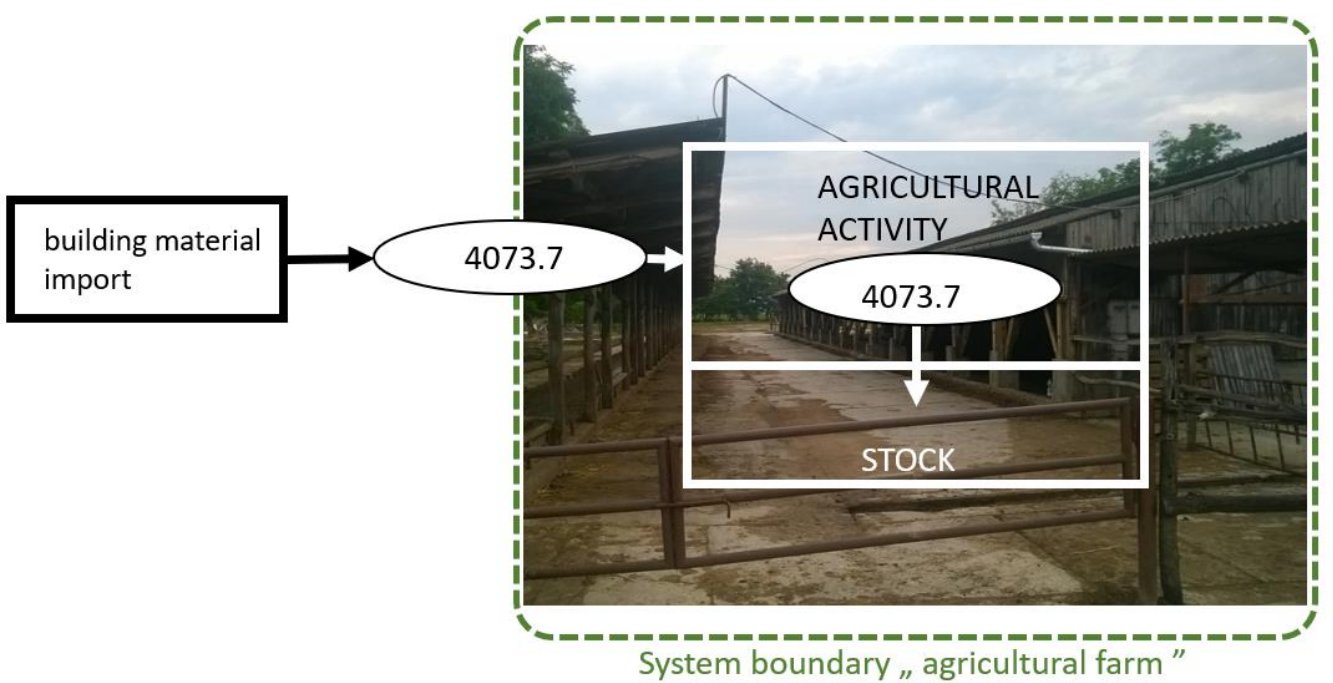

Figure 7. Farm-level growth of in-use building stock in tons as a result of a development project

\subsubsection{On national level:}

Based on the cost of the project in the case study 69 million Euros is enough for 709 such projects. This allows us to project the farm-level input to national level and assume that

$709 \times 4073.7$ tons $=2888253.3$ tons of building material inflow is going to be added to the building stock merely in the cattle raising branch of the agricultural sector in Hungary.

$$
\sum m_{\text {input }}=2888253.3 \text { tons }
$$

This result can be verified later in case we have access to the real data regarding construction materials of all awarded development projects in the country.

Figures 8. and 9. represent the results of the analysis. The difference between the information held by the figures is that Figure 9. indicates that other activities are also present within the system boundary. Both types of figures are appropriate for representing the results. 


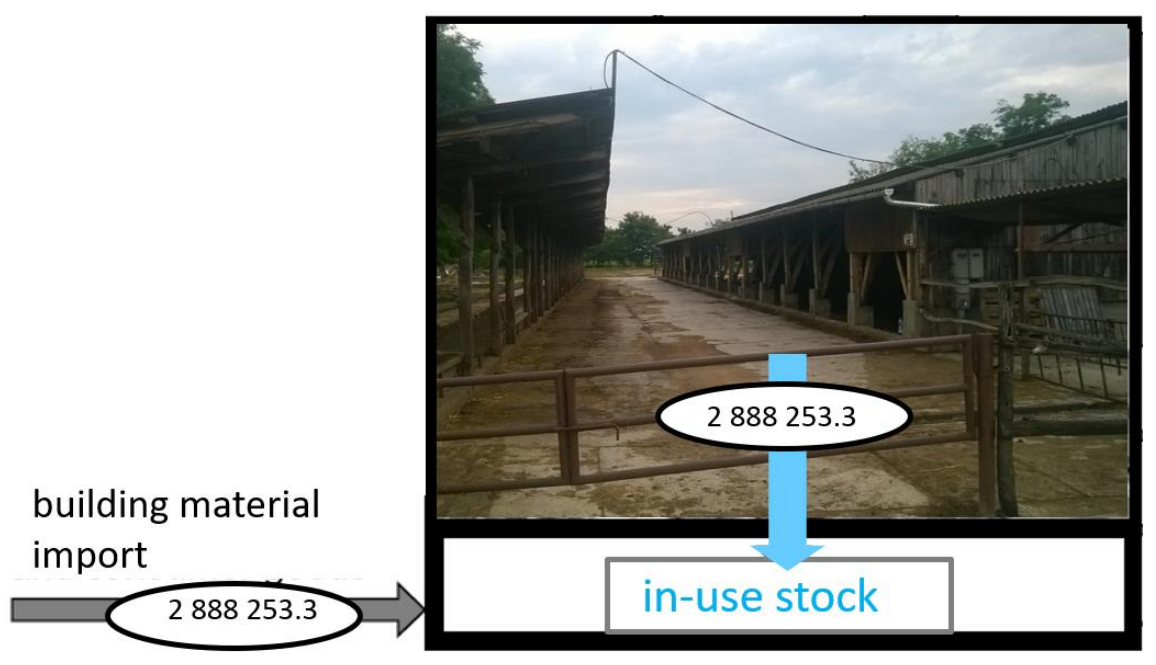

Figure 8. National-level growth of in-use building stock in tons as a result of a development project in Hungary

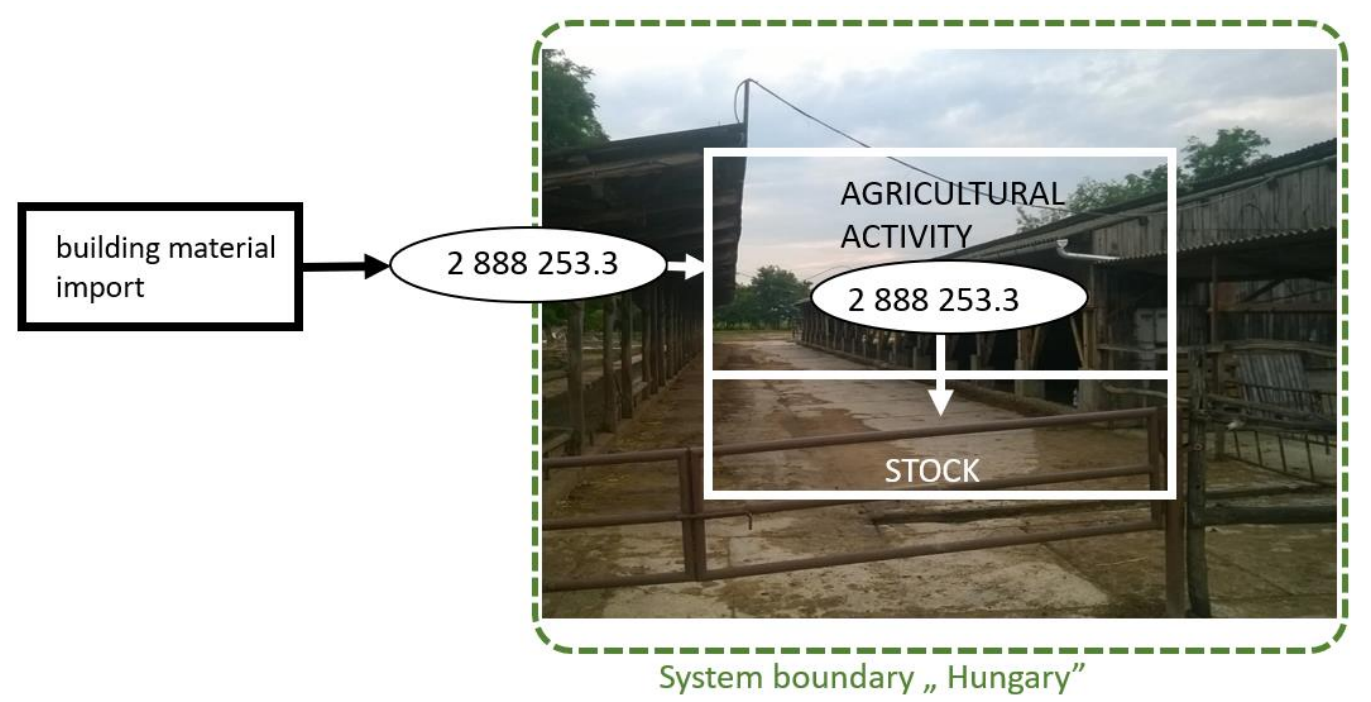

Figure 9. National-level growth of in-use building stock in tons as a result of a development project in Hungary

\section{Discussion and Conclusion}

The results we introduce in this study uses the database of a construction project carried out as part of an ongoing rural development program in the country allowing to assume that the building material stock in the agricultural sector is grown in a rate proportional to the available financial funding until 2020.

The results answer the aims of the study as long as it informs us about the growths of building stock in the investigated sector.

We need to admit however that the estimated value is not reliable since it is not sure that the same rate of recycling prevails for other sites or the same materials are chosen for example. Anyhow these results refer to the question of resource efficiency in the long run as it may contribute to a database 
which does not even exist in Hungary for agricultural buildings. Inventory database development is an inevitable measure in order to make MFA become a tool to design the anthropogenic metabolism in the future as it is offered in [4].

The result of the study can be used as a supplementary information in more remarkable research works. The estimated results may be verified or corrected using real object data derived from awarded tenders after the end of the funding period. It may also motivate decisionmakers define other expectations in further funding regarding resource efficiency.

\section{Acknowledgements}

We would like to acknowledge the two anonymous reviewers for their positive and constructive comments on early versions of this manuscript. We would also like to acknowledge the organizer of the workshop on the Size of the Society since it was the driving factor of this study.

\section{References}

\section{[1] Agenda21}

[2] A. Ruuska - T. Häkkinen (2014) Material Efficiency of Building Construction. VTT Technical Research Centre of Finland, Tekniikantie 4, 02044 VTT Finland; Buildings 2014, 4, 266-294; doi:10.3390/buildings4030266

[3] Baumit Mozaik Vakolat Mono

[4] P.H. Brunner - H. Rechberger (2004) Practical Handbook of Material Flow Analysis. Lewis Publishers, Boca Raton, 2004.

[5] CAP in your country -Hungary, European Commission November 2016.

[6] W. Q. Chen - T. E. Graedel (2015) In-use product stocks link manufactured capital to natural capital. Proc Natl Acad Sci USA 112(20), 6265-6270.

[7] Designing Agricultural Buildings I., Information sheet;

[8] D. Wiedenhofer - J. K. Steinberger - N. Eisenmenger - W. Haas (2015) RESEARCH AND ANALYSIS; Maintenance and Expansion - Modeling Material Stocks and Flows for Residential Buildings and Transportation Networks in the EU25. Journal of Industrial Ecology;Volume 19, Number 4

[9] EN 15978:2011. Sustainability of construction works-Assessment of environmental performance of buildings-Calculation method. 2011. Pauliuk S, Müller DB (2014), The role of in-use stocks in the social metabolism and in climate change mitigation, Glob Environ Change 24:132-142.

[10] European Union, The Construction Products Regulation (EU) No 305/2011 (CPR). 2011.

[11] F. Krausmanna - D. Wiedenhofera - C. Lauka - W. Haasa - H. Tanikawab - T. Fishmanb - A. Miattob - H. Schandld - H. Haberla (2017) Global socioeconomic material stocks rise 23-fold over the 20th century and require half of annual resource use, Edited by William C. Clark, Harvard University, Cambridge, MA, and approved January 5, 2017

[12] Gy. Ängelkott Bocz (2012) Reutilisation of Agricultural Buildings; Tourism and Sustainability in the Swedish Periurban Context, Alnarp; Doctoral Thesis; Swedish University of Agricultural Sciences; Alnarp 2012 
[13] G. Habert - Y. Bouzidi - C. Chen - A. Jullien (2010) Development of a depletion indicator for natural resources used in concrete. Resour. Conserv. Recycl., 54, 364-376.

[14] H. Weisz - S. Suh - T. E. Graedel (2015) The role of manufactured capital in sustainability. Industrial Ecology:PNAS May 19, 2015. 112 (20) 6260-6264; published ahead of print May 18, 2015.

[15] https://www.palyazat.gov.hu/vp2-4113-16-szarvasmarhatart-telepek-korszerstse

[16] https://www.thoughtco.com/sectors-of-the-economy-1435795

[17] Leier Castrum térkő

[18] Lindab Coverline $®$ | Műszaki információ, Burkolati rendszerek

[19] Magyarország mezőgazdasága, 2013 (Gazdaságszerkezeti összeírás - előzetes adatok), Központi Statisztikai Hivatal, 2014.01.

[20] Material flow analysis ( $\mathrm{mfa}$ ) for resource policy decision support, Position Paper of the Interest Group on the Sustainable Use of Natural Resources on the needs for further development of MFA-based indicators; Klagenfurt, Dessau, Wien, Edinburgh, Rome, London, Dublin, Bilbao, Bern, 11.09.2009

[21] J. A. Mathews - H. Tan (2016) Circular economy: Lessons from China. Nature 531(7595): 440442.

[22] Z. Michael - T. Hauschild - T. Ekvall - J. Guine'e - R. Heijungs - S. Hellweg - A. Koehler - D. Pennington - S. Suh (2009) Review Recent developments in Life Cycle Assessment, Go" ran Finnveden. Journal of Environmental Management 91 1-21; doi:10.1016

[23] OECD (2011), Resource Productivity in the G8 and the OECD-A Report in the Framework of the Kobe $3 R$ Action Plan (Organisation for Economic Co-operation and Development, Paris)

[24] P. Femenías, Dr. Arch.1, 2 Colin FUDGE, Prof. 1, Potentials and challenges for sustainable retrofitting of nondomestic buildings: a UK perspective

[25] S. Pauliuk - D. B. Müller (2014) The role of in-use stocks in the social metabolism and in climate change mitigation. Glob Environ Change DOI: 10.1016/j.gloenvcha.2013.11.006 24:132-142

[26] R. Ortlepp - K. Gruhler - G. Schiller - C. Deilmann (2015) The other "half of the city" - analysis of non-residential building stock and its materials. Smart and Sustainable Built Environment; ISSN: 2046-6099

[27] Sustainability of construction works-Environmental product declarations-Core rules for the product category of construction products, Buildings 2014, 4, 266-294; doi:10.3390/buildings4030266

[28] W. R. Stahel (2016) The circular economy. Nature 531(7595):435-438.

[29] UNEP (2011) Decoupling Natural Resource Use and Environmental Impacts from Economic Growth (United Nations Environment Programme, Nairobi)

[30] J. H. P. Van der Vaart (2005) Towards a new rural landscape: consequences of non-agricultural reuse of redundant farm buildings in Friesland. Landscape and Urban Planning, 70, 143-152.

[31] N.F.L. Waney - Y. Soemarno - B. Polii (2014) Developing Indicators of Sustainable Agriculture at Farm Level. IOSR Journal of Agriculture and Veterinary Science (IOSR-JAVS) e-ISSN: 2319-2380, p-ISSN: 2319-2372.Volume 7, Issue 2 Ver. II, PP 42-53

[32] Where is the wealth of nations? THE WORLD BANK Washington, D.C. Measuring Capital for the 21st Century; ISBN-10: 0-8213-6354-9 ISBN-13: 978-0-8213-6354-6 
International Journal of Engineering and Management Sciences (IJEMS) Vol. 3. (2018). No. 5

DOI: 10.21791/IJEMS.2018.5.30.

[33] T. O. Wiedmann - H. Schandl - M. Lenzen - D. Moran - S. Suh - J. West - K. Kanemoto (2013) The material footprint of nations. Proceedings of the National Academy of Sciences, DOI $10.1073 /$ pnas. 1220362110 